\section{Covid-19: England comes into line with rest of UK on recording deaths}

Cite this as: BMJ 2020;370:m3220 http://dx.doi.org/10.1136/bmj.m3220 Published: 13 August 2020

\section{Shaun Griffin}

A month after the "urgent" review promised by England's health secretary, Public Health England (PHE) has announced new reporting definitions that bring England into line with Wales, Scotland, and Northern Ireland in how it records deaths from covid-19. However, experts warn that some deaths will still be missed by this new approach.

PHE's analysis showed that 88\% of deaths from covid-19 in England occurred within 28 days of a positive test result, while $96 \%$ occurred within 60 days or had covid-19 on the death certificate. As a result, rather than counting anyone who had ever tested positive as a covid associated death, PHE will now use two definitions of death with covid-19 in England.

The first definition is death within 28 days of the first covid positive swab date. The second is death of someone with a laboratory confirmed positive covid-19 test who either died within 60 days of the first swab or, if covid-19 is mentioned on the death certificate, died more than 60 days after the first swab. PHE will now publish the 28 day figures daily and the 60 day figures weekly.

Under the 28 day definition England has 5377 fewer deaths than previously reported ( $36695 v 42072$ ), while the UK figure (as of 12 August) is 41329.

\section{Frustration}

Announcing the new approach-developed with the devolved administrations and the UK Statistics Authority-John Newton, PHE's director of health improvement, said, "The way we count deaths in people with covid-19 in England was originally chosen to avoid underestimating deaths caused by the virus in the early stages of the pandemic.

"Our analysis of the long term impact of the infection now allows us to move to new methods, which will give us crucial information about both recent trends and overall mortality burden due to covid-19."

Last month Carl Heneghan, director of the Centre for Evidence-Based Medicine at the University of Oxford, expressed his frustration with discrepancies between PHE's and the Office for National Statistics' reporting measures. ${ }^{1}$

Heneghan and his colleague, Jason Oke of the Nuffield Department of Primary Care Health Sciences at the University of Oxford, said that the new 28 day definition was "a more accurate and sensitive measure of the immediate impact of covid on deaths [which] allows us to better determine if deaths related to covid-19 are trending up or down."

They consider PHE's longer time frame to be important and say that it should be used to conduct in-depth analyses of the long term problems resulting from covid.

\section{Missed deaths}

David Spiegelhalter, chair of the Winton Centre for Risk and Evidence Communication at the University of Cambridge, said, "The 28 day limit marks an improvement ... but does exclude those who die more than a month after testing, even if they have covid on the death certificate. Including deaths up to 6o days, and later covid registered deaths, seems even better, but still excludes people who were not tested.

"This is a complex area, and there is no truly 'correct' count. The Office for National Statistics figure based on registrations should still be considered the best available, but of course even this does not include additional excess deaths that do not have covid on their certificate."

He added, "PHE have been consistently poor in clarifying both who is included as a covid death and the inevitable delays in reporting, and their dashboard has given the strong impression that the daily count is the actual number of deaths the day before.

"This in turn has influenced how the number is reported by the media and is deeply misleading at this stage of the epidemic, when the reported and the actual daily counts can be very different. I desperately hope that PHE can do more to prevent misinterpretation."

PHE's revised definitions do not significantly change the UK's position in Europe. Heneghan and Oke said, "In terms of total deaths, the UK (and England) remain in the same position above Italy," adding that "the UK's death rate (at 609 deaths per million population) is similar to Italy (583) and Spain (611) and above France (465), whereas England's death rate (at 655 deaths per million) remains higher.” 
This article is made freely available for use in accordance with BMJ's website terms and conditions for the duration of the covid-19 pandemic or until otherwise determined by BMJ. You may use, download and print the article for any lawful, non-commercial purpose (including text and data mining) provided that all copyright notices and trade marks are retained.

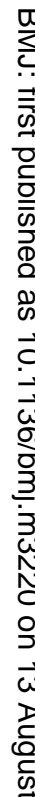

N

응

$\stackrel{\circ}{\circ}$

임

$\stackrel{10}{2}$

$\overrightarrow{\overrightarrow{0}}$

龸

گ

¿

옳

웅

N

글.

N

ס

음

$\stackrel{0}{\rightarrow}$

뭉

우

ญ

হ)

ᄋి

흘. 